\title{
The Effects of Lignocellulosic Fillers on Mechanical, Morphological and Thermal Properties of Wood Polymer Composites
}

\section{Učinci lignoceluloznih punila na mehanička, morfološka i toplinska svojstva drvno- plastičnih kompozita}

\author{
Original scientific paper • Izvorni znanstveni rad \\ Received-prispjelo: 2. 12. 2016. \\ Accepted - prihvaćeno: 30. 8. 2017. \\ UDK: $630 * 863.319 ; 630 * 864.26$ \\ doi:10.5552/drind.2017.1709
}

\begin{abstract}
The aim of this study was to investigate some of the physical, mechanical, thermal and morphological properties of wood flour and cellulose fiber filled polypropylene composites. Polypropylene as a polymer matrix and wood flour and cellulose fibers were used as reinforcing fillers to prepare the composites by using a single screw extruder. Physical properties such as density, mechanical properties such as flexure strength and flexure modulus, tensile strength and tensile modulus, and impact strength, thermal behavior with thermogravimetric analysis (TGA/DTA), and morphological characterization with scanning electron microscopy (SEM) of the composites were determined. The density of the composites was found to increase with the addition of fillers. The mechanical properties of the composites showed that the flexure and tensile strength for the composites with wood flour was higher than the composites with cellulose fibers, whereas flexure and tensile modulus, and impact strength for the composites with cellulose fibers was found to have higher values as compared to the composites with wood flour. SEM pictures showed that particles and fibers dispersed to different locations in polypropylene matrix. According to the TGA results, thermal degradation of all the composites was found to be lower compared to neat polymer.
\end{abstract}

Keywords: wood polymer composites, natural fillers, filler rate, mechanical properties, morphological characterization, thermal stability.

SAŽETAK • Cilj istraživanja bio je ispitati neka fizikalna, mehanička, toplinska i morfološka svojstva polipropilenskih kompozita s drvnim brašnom ili celuloznim vlaknima kao punilom. Polipropilen kao polimerna matrica te drvno brašno ili celulozna vlakna kao punilo za ojačanje upotrijebljeni su za izradu kompozita uz pomoć jednostrukoga vijčastog ekstrudera. Istraživanjem su određena fizikalna svojstva kompozita, npr. gustoća, te mehanička svojstva kao što su čvrstoća pri savijanju i modul savitljivosti, vlačna čvrstoća i modul elastičnosti te savojna žilavost. Usto je termogravimetrijskom analizom (TGA/DTA) ispitano toplinsko ponašanje kompozita, a skeniranjem elektronskim mikroskopom (SEM) napravljena je morfološka karakterizacija uzorka. Utvrđeno je da se dodatkom

\footnotetext{
${ }^{1}$ Authors are professors at University of Bartın, Forest Industry Engineering Department, Bartın, Turkey. ${ }^{2}$ Author is lecturer at Bulent Ecevit University, Caycuma Vocational School, Furniture and Decoration Programme, Zonguldak, Turkey.

${ }^{1}$ Autori su profesori Sveučilišta u Bartinu, Zavod za industriju baziranu na šumi, Bartın, Turska. ${ }^{2}$ Autor je predavač Sveučilišta Bulent Ecevit, Strukovna škola Caycuma, Program za namještaj i dekoracije, Zonguldak, Turska.
} 
punila gustoća kompozita povećava. Rezultati ispitivanja mehaničkih svojstava pokazali su da su čvrstoća pri savijanju i vlačna čvrstoća kompozita s drvnim brašnom veće od čvrstoće kompozita s celuloznim vlaknima, dok su vrijednosti modula savitljivosti, modula elastičnosti i savojne žilavosti veće za kompozite s celuloznim vlaknima nego za kompozite s drvnim brašnom kao punilom. SEM slike pokazuju da se čestice drvnog brašna i celulozna vlakna raspršuju na različite lokacije u polipropilenskoj matrici. Prema rezultatima TGA analize, utvrđeno je da je toplinska degradacija kompozita s drvnim brašnom ili celuloznim vlaknima kao punilom manja od degradacije kompozita s čistim polimerom.

Ključne riječi: drvno-plastični kompoziti, prirodna punila, udjel punila, mehanička svojstva, morfološka karakterizacija, termička stabilnost

\section{INTRODUCTION 1. UVOD}

In the past, wood flour (WF) represented a sawmill waste that needed to be disposed of. Many waste utilization strategies have been introduced over the last century including bedding, composting, combustion, gas generation and use as feedstock for chemical industry. The use of WF as raw material for making new solids is the most positive use of the waste, because of versatility in application and its low energy costs (Ashori, 2008; Okamoto, 2008; Wechsler and Hiziroglu, 2007). Thermoplastic polymers are loaded as matrices in composite materials with the WF filler to save costs, as the WF is a by-product of timber processing (Najafi 2013; Aydemir et al., 2015, Yang and Nelson, 2006).

Wood-derived fillers have made significant contributions to the thermoplastic industry, which has led to the emergence of wood-plastic composites (WPCs) in the construction industry. Products such as decking, fencing, siding, window framing, and roof tiles are being introduced into the market. WPCs are also beginning to be used in the fields of construction, transportation, industrial, and consumer industries. Growing interest of renewable resources-based products is due to social and environmental concerns. Commercial thermoplastics such as polyethylene, polypropylene (PP), polyvinyl chloride, and polystyrene are commonly used in the manufacture of plastic/wood fiber composites (Sobczak et al., 2013; Bledzki and Gassan, 1999; Rowell et al., 1997; Oksman and Sain, 2008). Polymers are used in many areas, such as automotive, electronics, and different construction equipment (Aydemir et al., 2016; Kruenate et al., 2004). The use of technical and standard plastics has encouraged the application of natural fibers thanks to their low prices and steadily rising performance (Witting, 1994; Zor et al., 2016).

In wood industry, a large amount of wood waste is generated at different stages of wood processing and these by-products are mainly intended for landfill (Falk and McKeever 2004). The use of waste wood in wood plastic composites (WPCs) helps to offset these disposal costs. It was well established that waste wood in the form of wood flour, fibers or pulp is suitable as filler for polyolefin (Woodhams et al., 1984; Maiti and Singh, 1986; Valles-Rosales et al., 2016). In general, wood flour is used as filler for plastic, which tends to increase the stiffness of the composite but does not im- prove its strength. Natural fibers can be used to reinforce rather than fill a plastic, which increases the strength as well as stiffness. Wood and other lignocellulosic fibers typically have higher particle sizes than those of wood flour. Furthermore, the aspect ratio of the fiber can be increased. At a critical fiber length, stress is transferred from the matrix to the fiber, resulting in a stronger composite. Stress is efficiently transferred only if the bond between the matrix and fiber is good (Oswald and Menges, 1995).

The aim of this study was to determine the usability of waste wood flour and fibers from particleboard and fiberboard in the manufacturing process of wood plastic composites. Also, some physical, mechanical and morphological properties of wood plastic composites were examined.

\section{MATERIALS AND METHODS} 2. MATERIJALI I METODE

\subsection{Materials}

2.1. Materijali

Wood flours (WF) and cellulose fibers (CF) were supplied by particleboard and medium density fiberboard from a firm in Turkey. For testing in this study, beech was used for wood flours and scots pine was selected for cellulose fibers. All WF samples were made the same size in $0.5 \mathrm{~mm}$ sieve. CFs, between 1 and 3 $\mathrm{mm}$ in length, were used in study. Polypropylene (EH241) was supplied by PETKIM Inc, in Turkey. The properties of the PP - EH241 are listed in Table 1.

Table 1 Properties of polypropylene (EH241)

Tablica 1. Svojstva polipropilena (EH241)

\begin{tabular}{|c|c|}
\hline Properties / Svojstvo & \begin{tabular}{|c|} 
Values \\
Vrijednost
\end{tabular} \\
\hline $\begin{array}{l}\text { Melt flow index, g/10 min (at } 230{ }^{\circ} \mathrm{C} / 2.16 \mathrm{~kg} \text { ) } \\
\text { Indeks protoka taljenjem, g/10 min (pri } 230 \\
{ }^{\circ} \mathrm{C} / 2.16 \mathrm{~kg} \text { ) }\end{array}$ & 5 to 20 \\
\hline Density, g/cm / Gustoća, g/cm ${ }^{3}$ & 0.92 \\
\hline Water absorption, \% / Upijanje vode, \% & 0.1 \\
\hline $\begin{array}{l}\text { Processing temperature, }{ }^{\circ} \mathrm{C} \\
\text { Temperatura procesa, }{ }^{\circ} \mathrm{C}\end{array}$ & $160-170$ \\
\hline Tensile strength, MPa / Vlačna čvrstoća, MPa & 35 \\
\hline $\begin{array}{l}\text { Flexure modulus, GPa } \\
\text { Modul savitljivosti, GPa }\end{array}$ & 1.5 \\
\hline $\begin{array}{l}\text { Izod impact, notched, } \mathrm{kJ} / \mathrm{m}^{2} \\
\text { Otpornost na udarce, } \mathrm{kJ} / \mathrm{m}^{2}\end{array}$ & 2 \\
\hline
\end{tabular}




\subsection{Preparation of composites}

\subsection{Izrada kompozita}

WF and CFs were oven dried at $103 \pm 2{ }^{\circ} \mathrm{C}$ to obtain a moisture content less than $1 \%$. PP was used as matrix polymer, while WF and CFs were used as fillers. Loading ratios of WF and CFs were 10, 20, 30 and $40 \%$ wt. The formulations of the production are given in Table 2.

Table 2 Formulation of samples

Tablica 2. Sastav uzoraka

\begin{tabular}{|c|c|c|c|}
\hline \multirow{2}{*}{$\begin{array}{c}\text { Samples } \\
\text { Uzorci }\end{array}$} & \multicolumn{3}{|c|}{ Formulation, \% / Udjel, \% } \\
\cline { 2 - 4 } & PP & WF & CF \\
\hline PP & 100 & - & - \\
\hline WF10\% & 90 & 10 & - \\
\hline WF20\% & 80 & 20 & - \\
\hline WF30\% & 70 & 30 & - \\
\hline WF40\% & 60 & 40 & - \\
\hline CF10\% & 90 & - & 10 \\
\hline CF20\% & 80 & - & 20 \\
\hline CF30\% & 70 & - & 30 \\
\hline CF40\% & 60 & - & 40 \\
\hline
\end{tabular}

Legend / Legenda: PP - neat polypropylene / čisti polipropilenski uzorci; WF - wood flours as a filler / drvno brašno kao punilo; CF - cellulose fibers as a filler / celulozna vlakna kao punilo

The materials used in the compounding were first mixed to achieve better dispersion by a mechanical mixer for 15 minute. The obtained samples were extruded at $50 \mathrm{rpm}$ by a single screw extruder. During the extrusion, the zone temperatures ranged between 160 and $170^{\circ} \mathrm{C}$, the melting pressure of the extruder varied between 5 and 10 bars depending on material blends, the screw speed was $50 \mathrm{rpm}$, and the material output was $1 \mathrm{~kg} / \mathrm{h}$. After exiting the extrusion, the obtained compounds, which were in a melt state, were cooled and solidified directly in a water-cooling system, while being pulled with end drive conveyors. Then the solidified materials were pelletized through a pelletizer. Next, the pellets obtained were injection molded to obtain the test samples.

All samples were conditioned at $20{ }^{\circ} \mathrm{C}$ and $65 \%$ relative humidity prior to testing. First, the weights of samples were measured in air by a precision scale to the nearest $0.001 \mathrm{gr}$ and immersed in distilled water. Then, the density of the samples was measured by a water displacement technique according to ASTM D792-98.

Flexure strength (MOR), flexure modulus (MOE), tensile strength and tensile modulus (TM) were carried out according to ASTM D 790-03 Test Method 1 and ASTM D 638-03 Type I, respectively. These tests were conducted using a Zwick tester with a $10-\mathrm{kN}$ load cell capacity. Test speed rate of $0.2 \mathrm{in} / \mathrm{min}$ was used for all tests. The izod impact tests (IIS) were conducted according to ASTM D 256-06. The notches were provided with a NotchVIS machine (Ceast trademark) and tests were carried out with a Resil 50 B impact tester. The morphological properties of the samples were observed with a scanning electron microscope (SEM) (Phillips Electroscan 2020) with an accelerating volt- age of $5 \mathrm{kV}$ under nitrogen. The fracture parts of all samples were sputter-coated with gold using a Denton sputter coater for enhanced conductivity.

The thermal stability of all the composites was investigated using a TGA/DTA and DSC (Perkin Elmer, TA Instruments, USA). In TGA/DTA, the samples were heated from $25^{\circ} \mathrm{C}$ to $600{ }^{\circ} \mathrm{C}$ with a heating rate of $10{ }^{\circ} \mathrm{C} / \mathrm{min}$ and a nitrogen flow of $100 \mathrm{~mL} / \mathrm{min}$. The samples weighing about $10 \mathrm{mg}$ were used for the tests. Degradation temperatures at $10 \%$ weight loss $\left(T_{\% 10}\right)$ and $50 \%$ weight loss $\left(T_{\% 50}\right)$, maximum degradation temperature in the derivative thermogravimetric peaks (DTG ${ }_{\text {max }}$ ), and mass loss of the samples in the TGA cures were measured and compared with the results obtained. The differential scanning calorimeter (DSC) tests were performed on a DSC 2920 (Perkin Elmer, TA Instruments, USA) at a heating rate of $5{ }^{\circ} \mathrm{C} / \mathrm{min}$ under a nitrogen atmosphere. The samples weighed about $10 \mathrm{mg}$. To determine the crystallinity, $191.3 \mathrm{~J} / \mathrm{g}$ was used to pure PP enthalpy (Myers et al., 1991).

One-way analysis of variance (ANOVA) was performed to identify significant differences at the 99 \% confidence level. The Duncan test was used to determine the difference between groups. The important differences between formulations were shown with letters A, B, C, and D.

\section{RESULTS AND DISCUSSION 3. REZULTATI I RASPRAVA}

\subsection{Physical and mechanical properties}

3.1. Fizikalna i mehanička svojstva

In this study, WF and CFs were used as fillers to different density ratio such as $10 \%, 20 \%, 30 \%$ and 40 $\%$. Density of pure PP was determined as $0.89 \mathrm{~g} / \mathrm{cm}^{3}$. Addition of fillers increased the density of composites. The maximum densities for both the WF and CFs were found as $0.99 \mathrm{~g} / \mathrm{cm}^{3}$ and $0.98 \mathrm{~g} / \mathrm{cm}^{3}$ (Fig. 1). The difference between the density of the composites with WF and CFs was not statistically important. However, it was determined that the effect of WF on the composite density was higher than that of CFs. In another study, although the density of wood was $0.689-0.755 \mathrm{~g} / \mathrm{cm}^{3}$ and polymer matrix was $0.95 \mathrm{~g} / \mathrm{cm}^{3}$, the density of WF filled polymer composites was found to increase to $1.108 \mathrm{~g} / \mathrm{cm}^{3}$ (Ichazo et al., 2001).

Fig. 2 shows the tensile strength and TM values. According to Fig. 2, the addition of the fillers reduced tensile strength, while increasing the TM of the composites. Tensile strength of pure PP was $29.68 \mathrm{MPa}$, and tensile strength was found to decrease to 22.32 MPa for WF and 23.54 MPa for CFs, respectively, with the addition of the fillers. Tensile strength decreased by about $24.8 \%$ and $20.7 \%$ for the composites with $40 \% \mathrm{WF}$ and $40 \% \mathrm{CFs}$. Similar results were observed by Meyers et al. (1991) and Ichazo et al. (2001). The effect of cellulose fibers on the tensile strength of composites is lower than that of wood flour. This can be explained by fiber direction in the composites. The effect of fibers, which are perpendicular to the pulling direction, on the tensile strength 


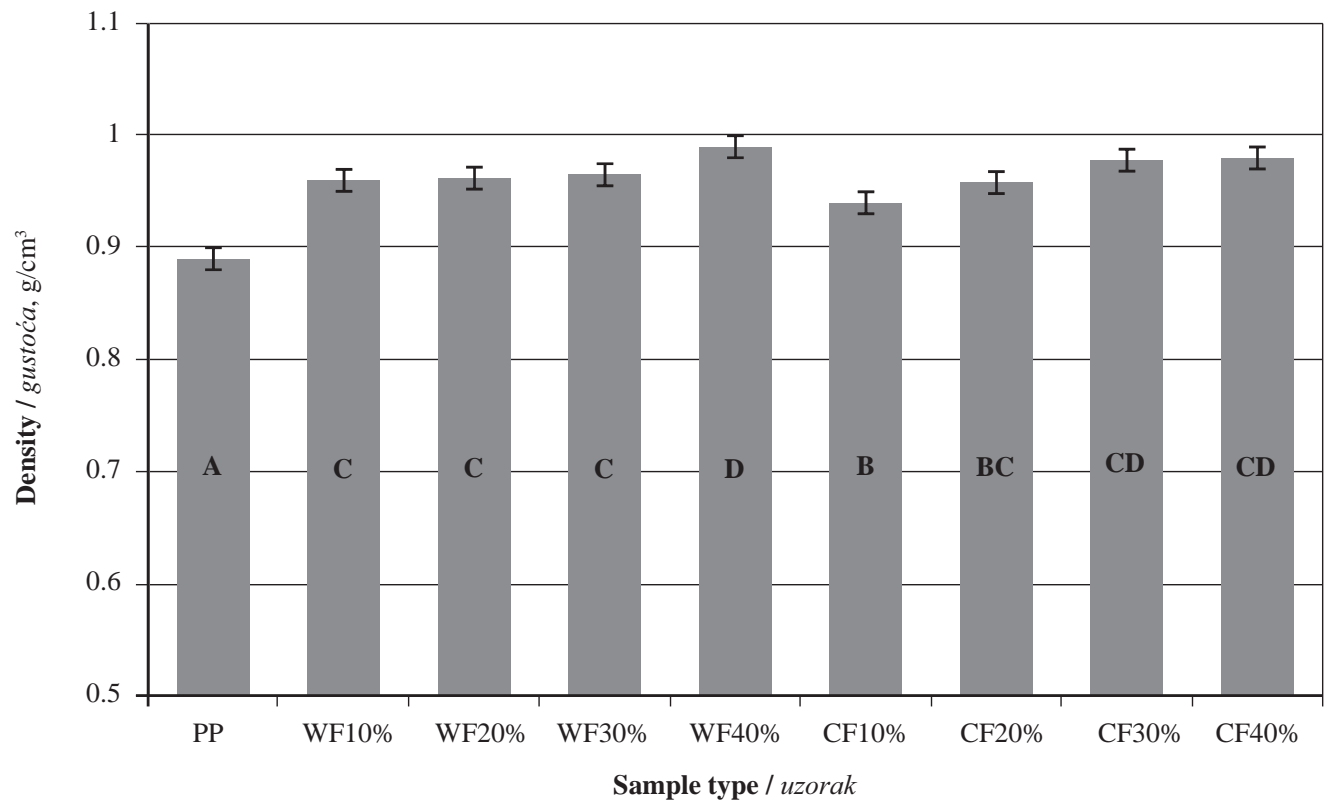

Figure 1 Densities of composites

Slika 1. Gustoća kompozita

is limited. Similar results were also reported by Raghu H (2006); Ismail H (2004). They investigated the effect of filler loading in some composites. They found that the lower tensile strength at $40 \%$ filler content could be referred to as ineffective stress between the particle-matrix interfaces due to weak interface adhesion.

According to Fig. 3, the addition of the fillers generally increased the MOR and MOE. The highest value of MOR and MOE was found as 47.32 MPa, 2.44 GPa for the composites with $30 \%$ CFs. $10 \%$ WF showed the lowest MOE with 1.4 GPa after control samples, the lowest MOR value was obtained from 40 \% CF samples as $42.29 \mathrm{MPa}$. This can be explained by fragile structure of cellulose fibers and rate of cellulose fiber. Since 40 \% CF rates in the PP mixing made difficult the performance of the extruder, CFs in the total mixing take up space as volume. For this reason, in the CF samples, MOE and MOR increased until rates of 30 $\%$ and decreasing began after $40 \%$ CF rates. Bouafif et al. (2009) reported that MOE of the wood polymer composites showed a steady increase with increasing filler content.

As shown in Fig. 4, the izod impact strength (IIS) of all composites was found to be higher than that of the pure PP. The highest values for the IIS were found as $106 \%$ and $35.32 \%$ for $40 \%$ CF and $40 \%$ WF, respectively, as compared to the PP samples.

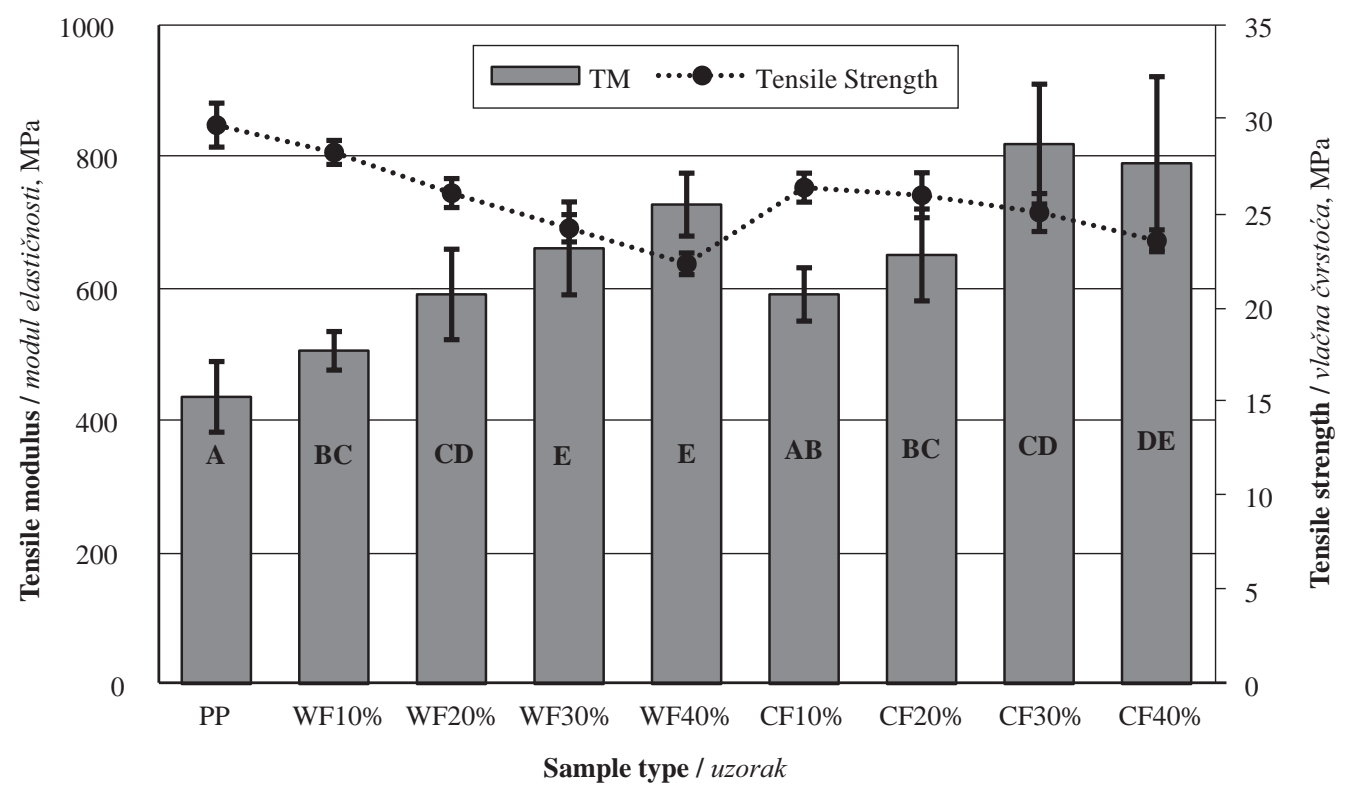

Figure 2 Tensile modulus (TM) and tensile strength values of composites Slika 2. Modul elastičnosti i vlačna čvrstoća kompozita 


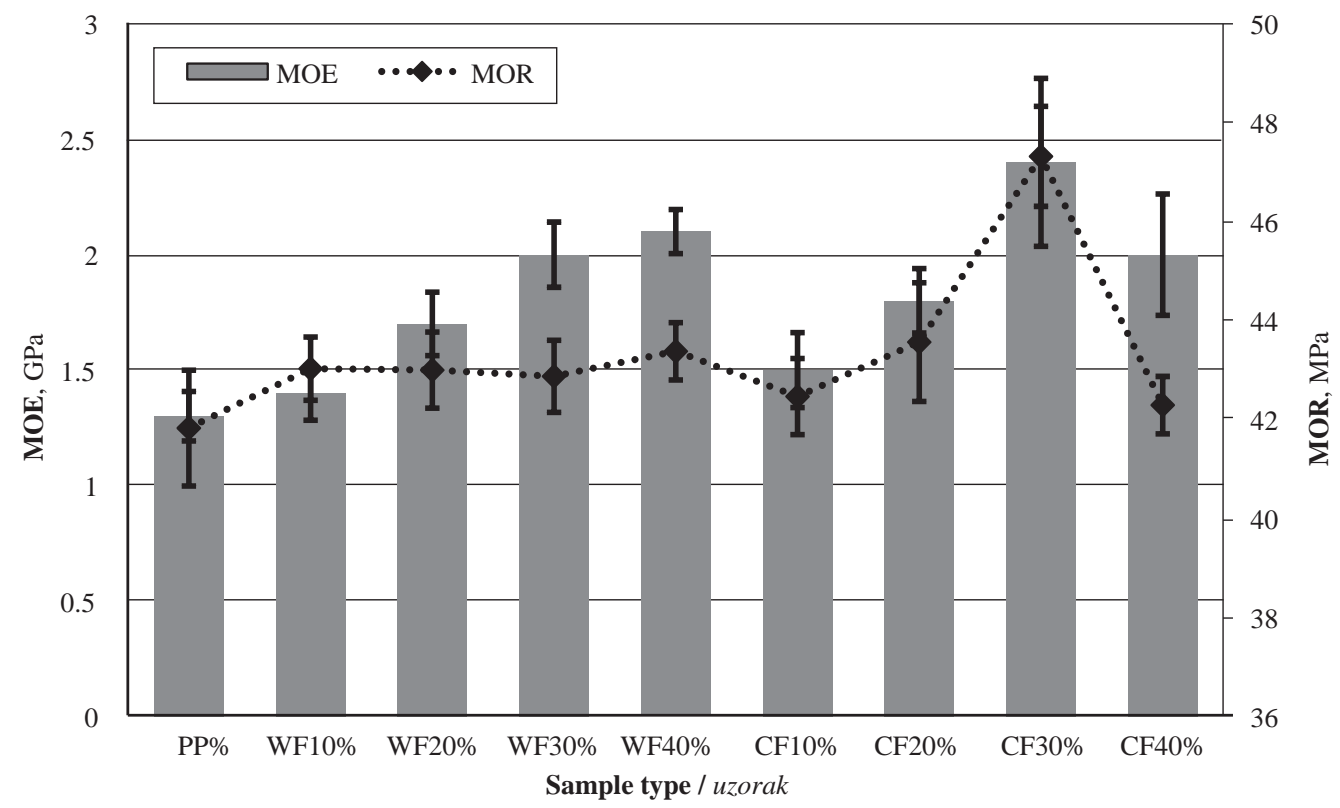

Figure 3 Flexure modulus (MOE) and flexure strength (MOR) values of composites

Slika 3. Vrijednosti modula savitljivosti (MOE) i čvrstoće kompozita pri savijanju (MOR)

\subsection{Morphological characterization}

3.2. Morfološka karakterizacija

The morphological characterization of the composites was investigated with SEM inside the samples. Fig. 5 presents a SEM micrograph of WF and CFs. It shows adhesion between WF and matrix. Although the amount of WF is increasing (10 \% Fig. 5-a, $20 \%$ Fig. 5-b, $30 \%$ Fig. 5-c, and $40 \%$ Fig. 5-d), it can be said that a homogeneous mixture is obtained. This statement is also supported by the increase in mechanical properties (MOR, and izod impact strength) of WF composites.

The SEM micrograph of the interactions between matrix and fillers is shown in Fig. 6. When comparing the interactions between WF and CFs with PP, WFs provided better compliance than CFs. Wood flour used in the study was milled by 0.5 mesh sieve. So, all of the wood flour is almost the same size. This case showed linear increase in mechanical properties of WF composites. On the other hand, the sizes of cellulose fibers varied between $3 \mathrm{~mm}$ and $7 \mathrm{~mm}$. CF $10 \%$ and CF 20 $\%$ demonstrated a homogeneous dispersion (Fig $6 \mathrm{a}-\mathrm{b}$ ), in CF $30 \%$ and CF $40 \%$ clustering in composites was observed (Fig $6 \mathrm{c}$-d). It is thought that using singlecylinder extruder in the study and the increase of CF content (from $10 \%$ to $40 \%$ ) led to this status. Khonsari et al. (2015) stated that wood flour geometry affected physical and mechanical properties of WPC.

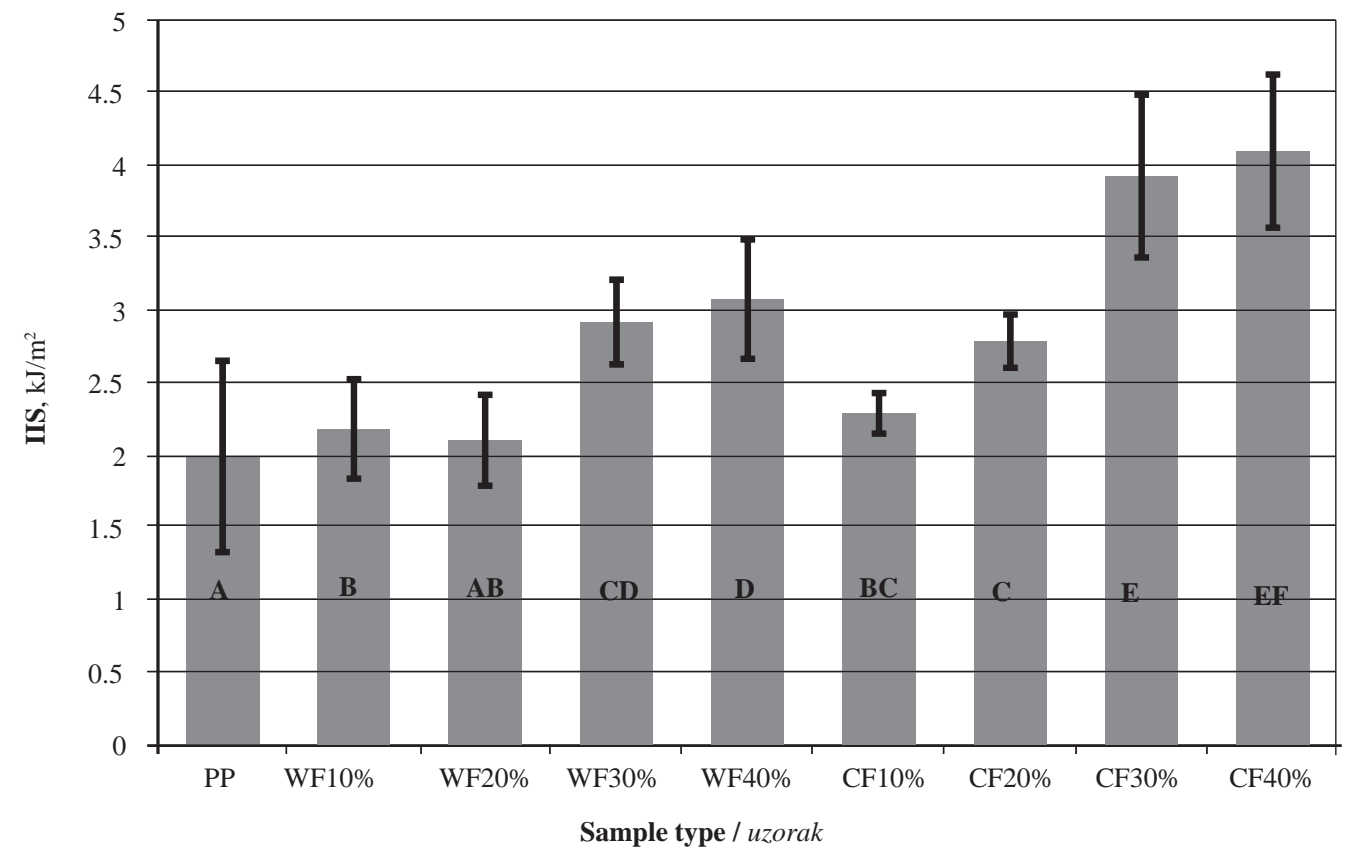

Figure 4 Izod impact strength (IIS) values of composites

Slika 4. Izod vrijednosti savojne žilavosti (IIS) kompozita 


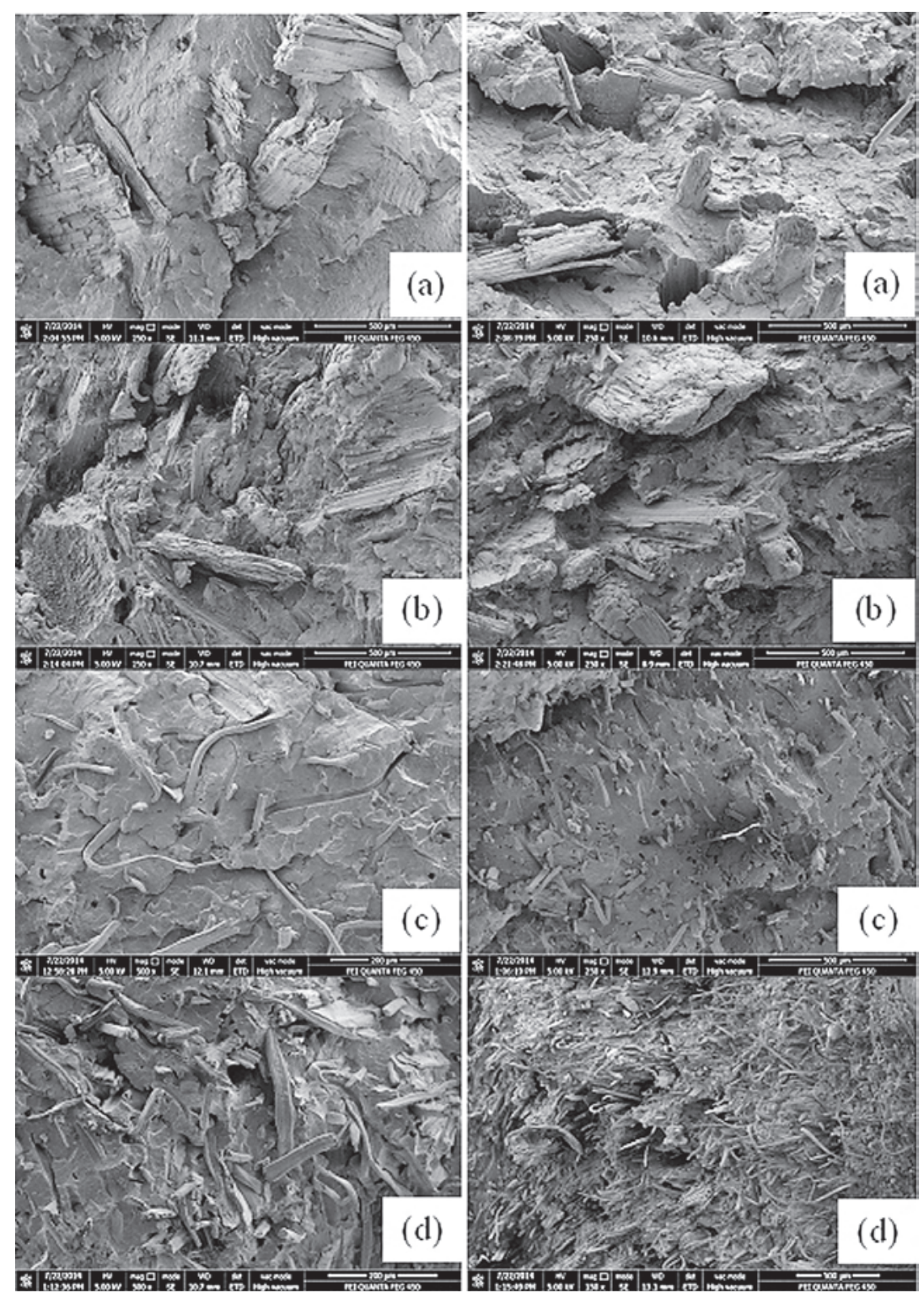

Figure 5 SEM pictures of WF composites (left side) and CF (right side) (a) $10 \%$, (b) $20 \%$, (c) $30 \%$ and (d) $40 \%$

Slika 5. SEM slike kompozita s drvnim brašnom (lijeva strana) i celuloznim vlaknima (desna strana): (a) 10 \%, (b) 20 \%, (c) $30 \%$ i (d) $40 \%$

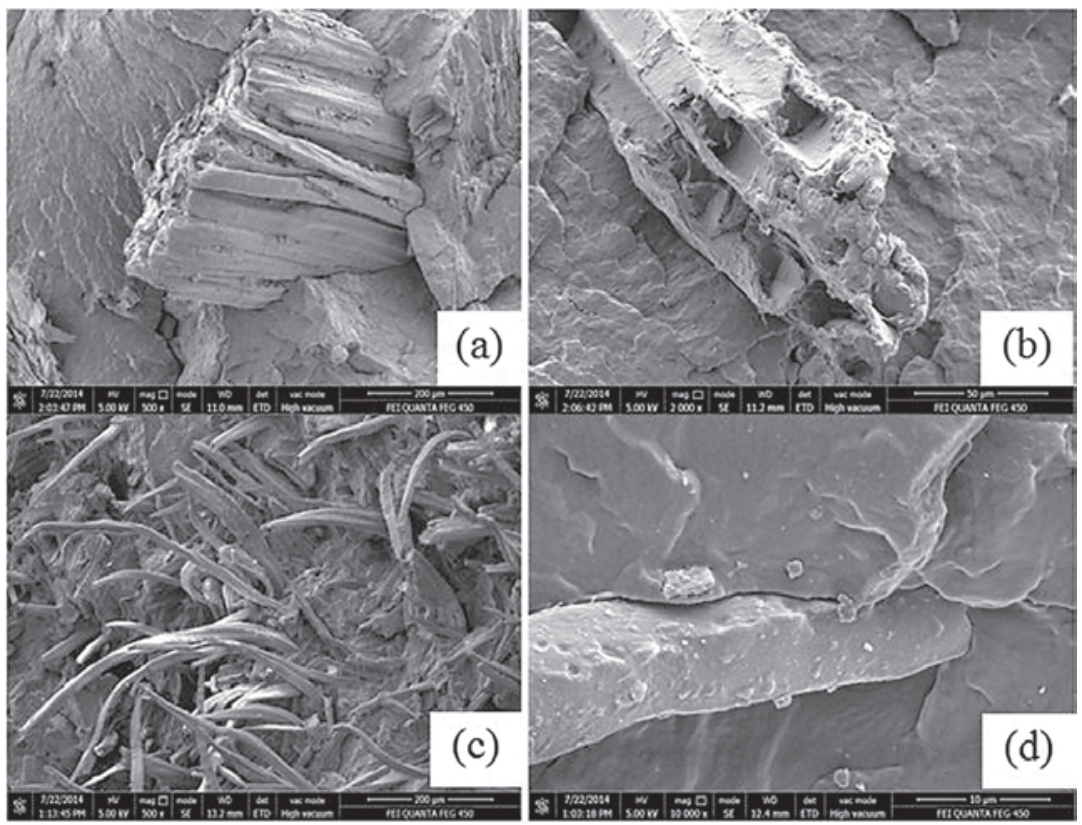

Figure 6 Comparison of interactions between WF and CFs with PP

Slika 6. Usporedba interakcije WF-a i PP-a s interakcijom CF-a i PP-a 


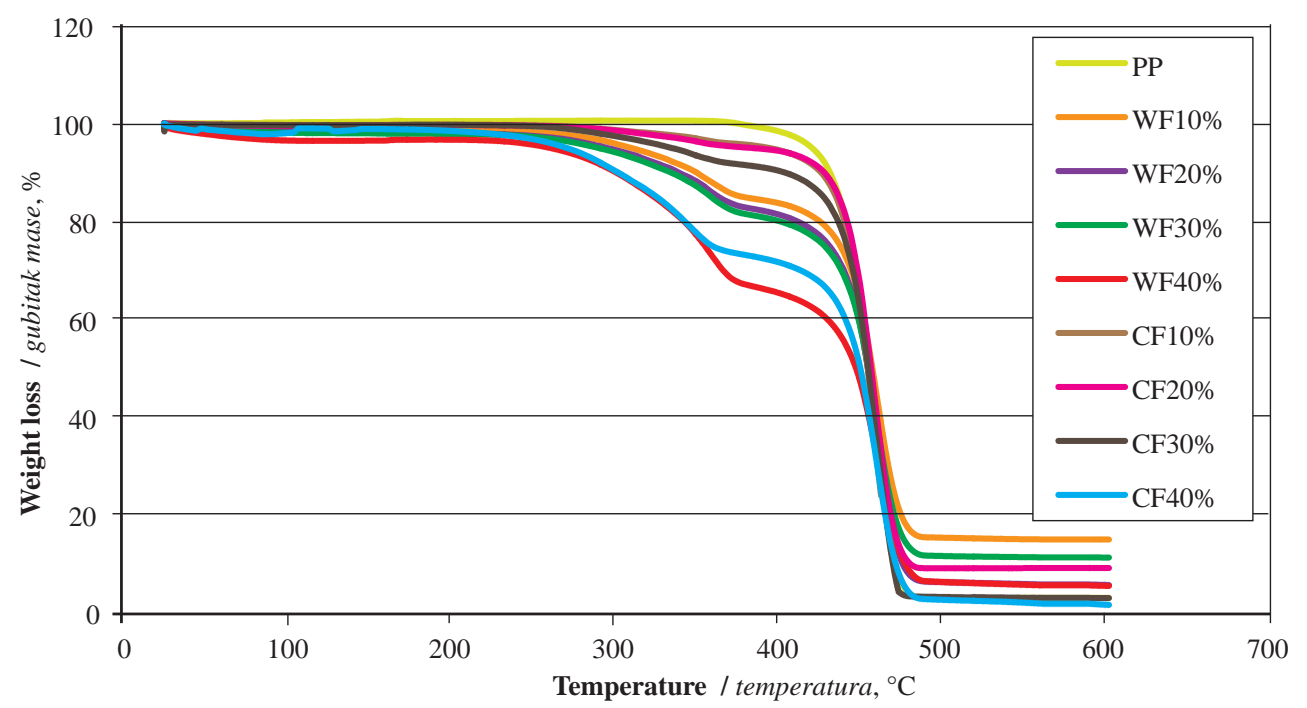

Figure 7 TGA curves of WPC

Slika 7. TGA krivulje drvno-plastičnih kompozita

\subsection{Thermal stability}

\subsection{Toplinska stabilnost}

Thermal stability of the composites is an important property for some application areas. For this reason, the thermal property of the composites obtained was investigated by using DSC, TGA and DTA. Fig. 7 shows TGA curves of the composites. It is well known that wood flour decomposes in the order of hemicellulose $\left(200-300^{\circ} \mathrm{C}\right)$, cellulose $\left(300-400^{\circ} \mathrm{C}\right)$, and lignin (200-900 ${ }^{\circ} \mathrm{C}$ ) (Joseph et al., 2003; Verbicky et al., 1988). According to Fig. 7, the fastest mass losses have been observed in WF 40 \% and CF $40 \%$ composites. On the other hand, CF $10 \%$ has the nearest curve to pure PP. Generally, the increasing amount of WF and/ or CF brings about decreasing levels of WPC weight loss at the high temperature.

Fig. 8 shows DTA curves, which present the degradation point of pure $\mathrm{PP}$ and $\mathrm{WF} / \mathrm{CF}$ composites.
There are two important points: melting point and degradation point. Endothermic peaks are at $165^{\circ} \mathrm{C}$ (melting point) and $460{ }^{\circ} \mathrm{C}$ (degradation point) in DTA curves. Interfacial interaction also plays a very important role in the degradation of polymeric nanocomposites. Better interfacial interaction allows particles to act as restriction sites for the movement of a polymer chain. This makes the scission of a polymer chain harder at lower temperature, and hence moves the degradation temperature of the material to a higher temperature. Moreover, improved interfacial interaction between additives and polymer chain, introduced by deeper penetration of smaller particles in the polymer matrix, will also limit the movement of the polymer chain (Khan et al., 2010).

DTG curves are shown in Fig. 9. The peaks of the composites were found to be between $370{ }^{\circ} \mathrm{C}$ and 470 ${ }^{\circ} \mathrm{C}$ at the value of $2800 \mathrm{mg} / \mathrm{min}$. This peak corresponds

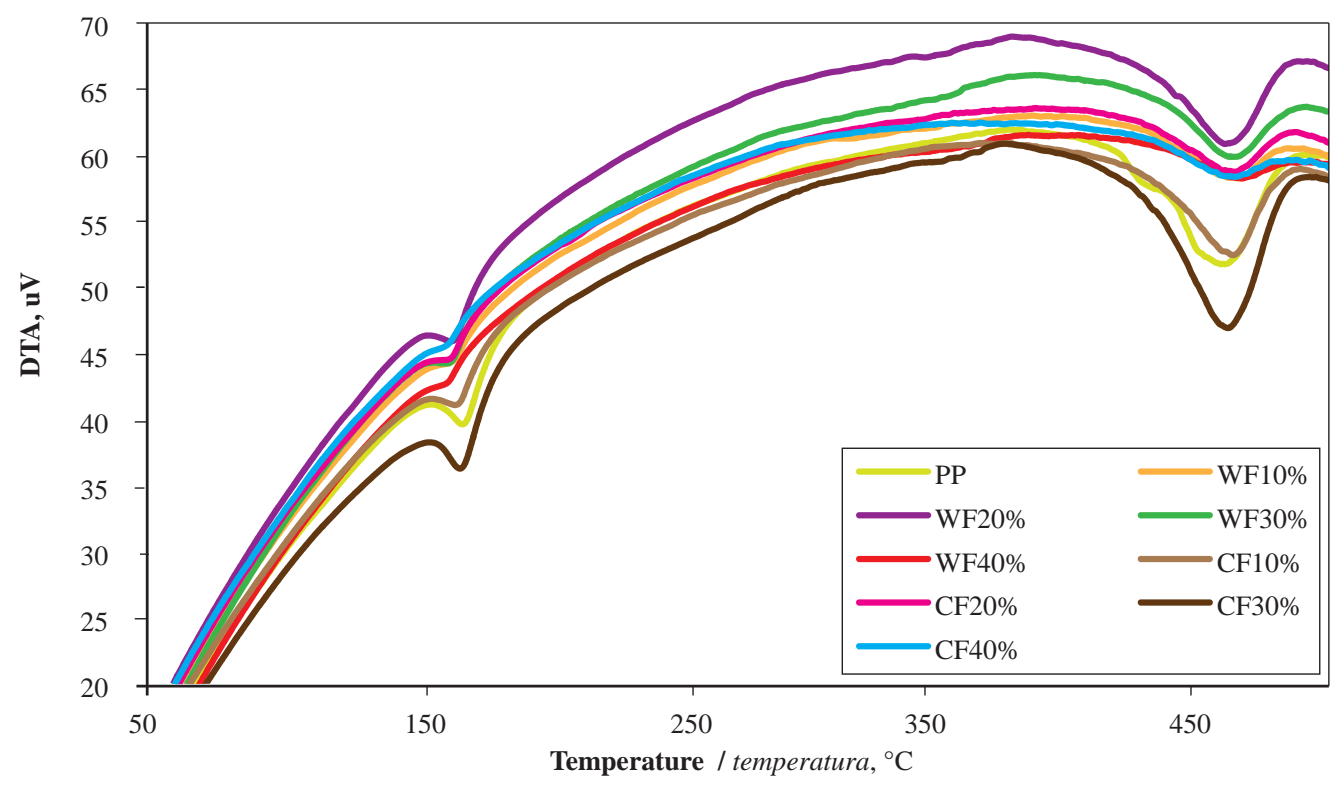

Figure 8 DTA curves of WPC

Slika 8. DTA krivulje drvno-plastičnih kompozita 


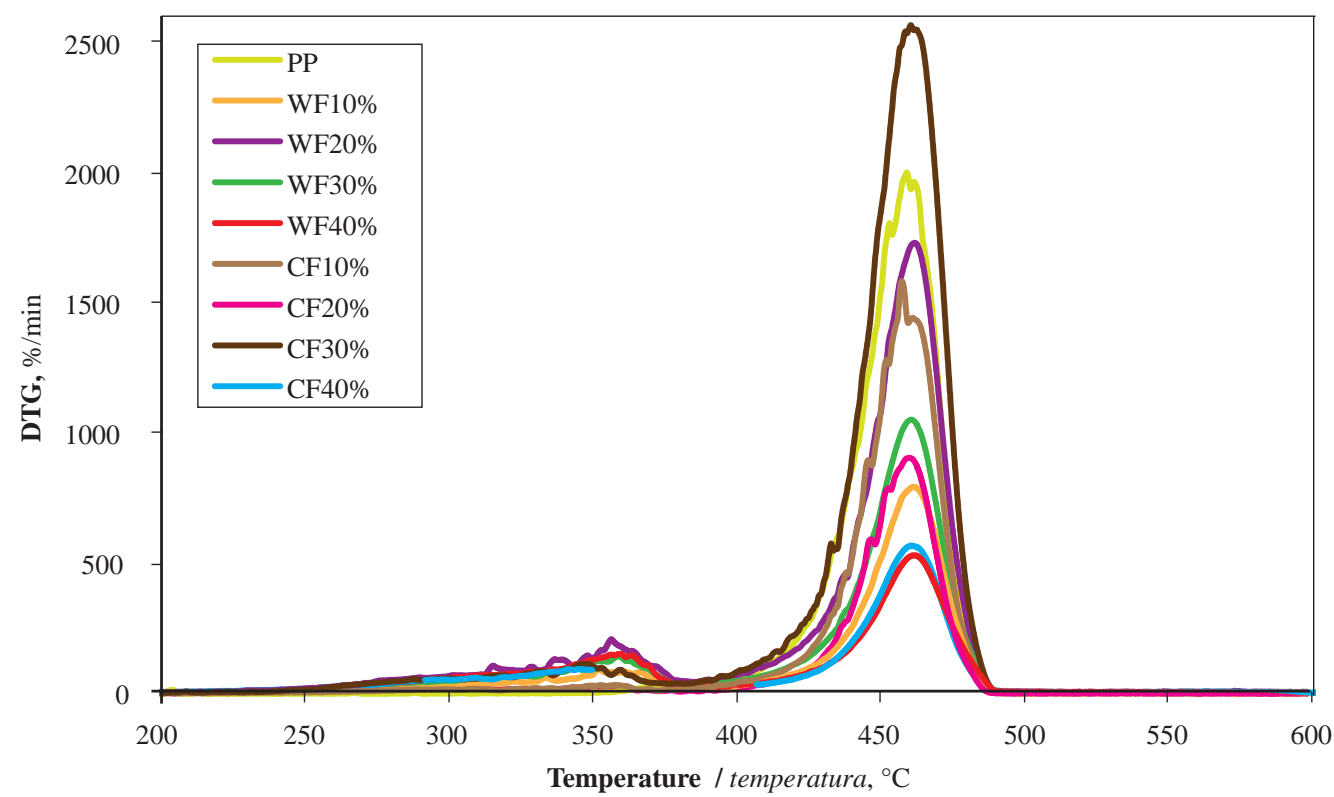

Figure 9 DTG curves of composites

Slika 9. DTG krivulje drvno-plastičnih kompozita

to the rupture of C-C chain bonds along with $\mathrm{H}$-abstraction at the site of rupture (Pandey, 1999; Roger, 2005). PP is strongly hygroscopic in nature and completely depleted at $426^{\circ} \mathrm{C}$ without the formation of any char residue (Baeza and Freer, 2001).

The results also show that, as the filler loading increased, the thermal stability of the composites slightly decreased, as the WF/CF content increased because of the lower thermal stability of WF/CF compared to the pure PP. The summary of the thermogravimetric analysis is presented in Table 3.

Table 4 shows DSC curves and summary DSC data of the composites with WF and CFs. The $T_{\mathrm{m}}$ and $T_{\mathrm{c}}$ values of the composites changed a little bit with the addition of WF and CFs and the composites have different $T_{\mathrm{m}}$ and $T_{\mathrm{c}}$ values. The melting enthalpy $\left(\Delta H_{\mathrm{m}}\right)$, the crystallization enthalpy $\left(\Delta H_{c}\right)$ and the degree of crystallinity decreased with the addition of WF and CFs. Similar results were also reported by other researchers for MCC filled composites. The DSC results also indicated that the crystallinity $\left(X_{c}\right)$ decreased with increasing MCC level because of the inability of poly- mer chains to be fully incorporated into the growing crystalline lamellae (Kızıltaş, 2009). The glass transition temperature provides important evidence for blend miscibility (Liang, 2007). All composites showed only one Tg value and the $T_{\mathrm{g}}$ values of composites are between $110^{\circ} \mathrm{C}$ and $120^{\circ} \mathrm{C}$ as WF/CF loading increased. Fig. 10 shows dual melting peaks in all composites.

\section{CONCLUSIONS \\ 4. ZAKLJUČAK}

Wood flour (WF) and cellulose fiber (CF) composites were produced by melt compounding and these composites were investigated for four different loadings based on the properties of polypropylene composites. The results indicated that there were increases in the density and mechanical properties, such as TM, MOE and IIS. However, both the tensile strength and MOR characteristics were decreased. It was found that the thermal stability of the composites decreased with both WF and CFs. The SEM pictures showed that there were some agglomerations in morphological structure

Table 3 Summary of thermogravimetric analysis

Tablica 3. Kratki pregled termogravimetrijske analize kompozita

\begin{tabular}{|c|c|c|c|c|c|c|}
\hline \multirow[b]{2}{*}{$\begin{array}{c}\text { Samples } \\
\text { Uzorci }\end{array}$} & \multicolumn{3}{|c|}{ TGA Analysis / TGA analiza } & \multicolumn{2}{|c|}{ DTA Analysis / DTA analiza } & \multirow{2}{*}{$\begin{array}{c}\text { DTG } \\
T_{\text {dmax }} \\
{ }^{\circ} \mathrm{C}\end{array}$} \\
\hline & $\begin{array}{l}T_{10 \%} \\
{ }^{\circ} \mathrm{C}\end{array}$ & $\begin{array}{l}T_{50 \%} \\
{ }^{\circ} \mathrm{C}\end{array}$ & $\begin{array}{c}\boldsymbol{T}_{85 \%} \\
{ }^{\circ} \mathrm{C}\end{array}$ & $\begin{array}{l}\text { Melting point } \\
\text { Točka taljenja } \\
{ }^{\circ} \mathrm{C}\end{array}$ & $\begin{array}{c}\text { Degradation point } \\
\text { Točka degradacije } \\
{ }^{\circ} \mathrm{C}\end{array}$ & \\
\hline $\mathrm{PP}$ & 431.7 & 455.6 & 468.6 & 169.9 & 460.6 & 459.3 \\
\hline WF10 & 350.1 & 457.6 & 464.9 & 169.5 & 466.2 & 462.8 \\
\hline WF20 & 338.9 & 454.8 & 471.3 & 166.5 & 463.4 & 462.3 \\
\hline WF30 & 334.1 & 455.1 & 476.9 & 164.4 & 465.5 & 461.5 \\
\hline WF40 & 300.8 & 447.6 & 471.6 & 164.1 & 466.2 & 461.9 \\
\hline CF10 & 426.2 & 454.7 & 465.9 & 167.9 & 464.9 & 457.7 \\
\hline CF20 & 428.2 & 456.8 & 472.6 & 165.4 & 466.4 & 460.8 \\
\hline CF30 & 403.1 & 455.1 & 467.9 & 168.8 & 465.9 & 460.9 \\
\hline CF40 & 302.2 & 450.3 & 468.3 & 163.5 & 466.2 & 461.9 \\
\hline
\end{tabular}




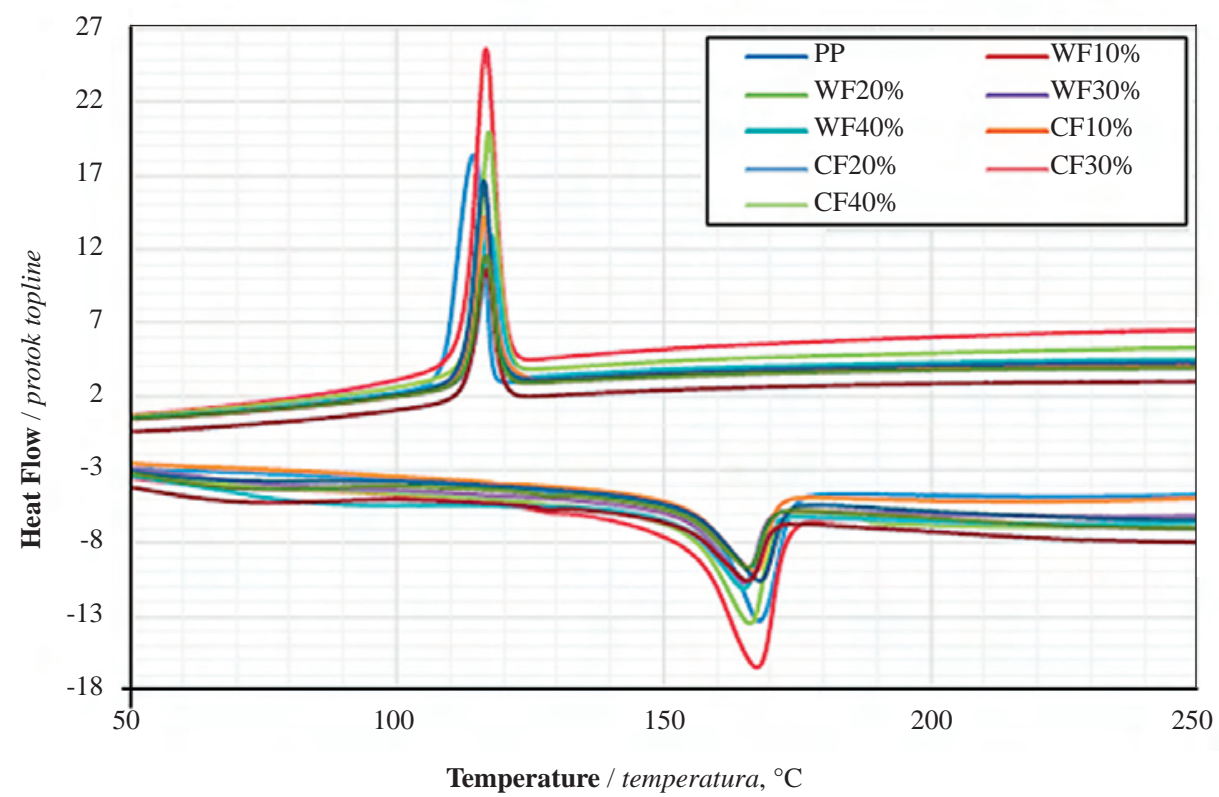

Figure 10 DSC curves of composites

Slika 10. DSC krivulje drvno-plastičnih kompozita

Table 4 Summary of differential scanning calorimetry

Tablica 4. Kratki pregled rezultata diferencijalne skenirajuće kalorimetrije

\begin{tabular}{|c|c|c|c|c|c|c|c|}
\hline \multirow{3}{*}{$\begin{array}{c}\text { Samples } \\
\text { Uzorci }\end{array}$} & \multicolumn{3}{|c|}{ Cooling / Hlađenje } & \multicolumn{3}{|c|}{ Heating / Zagrijavanje } & \multirow{3}{*}{$X_{c}, \%$} \\
\hline & $T_{\text {Conset }}$ & $T_{\mathrm{c}}$ & $\Delta \boldsymbol{H}_{\mathrm{c}}$ & $T_{\text {monset }}$ & $T_{\mathrm{m}}$ & $\Delta \boldsymbol{H}_{\mathrm{m}}$ & \\
\hline & ${ }^{\circ} \mathrm{C}$ & ${ }^{\circ} \mathrm{C}$ & $\mathbf{J} / \mathbf{g}$ & ${ }^{\circ} \mathrm{C}$ & ${ }^{\circ} \mathbf{C}$ & $\mathbf{J} / \mathbf{g}$ & \\
\hline $\mathrm{PP}$ & 117.4 & 113.9 & 99.8 & 157.3 & 168.2 & 88.8 & 46.4 \\
\hline WF10\% & 120.7 & 116.8 & 84.9 & 154.6 & 167.5 & 82.5 & 43.1 \\
\hline WF20\% & 120.4 & 116.9 & 75.9 & 154.3 & 166.1 & 73.1 & 38.2 \\
\hline WF30\% & 120.9 & 116.9 & 68.9 & 153.9 & 165.4 & 66.4 & 34.7 \\
\hline WF40\% & 121.4 & 117.1 & 61.8 & 153.3 & 165.1 & 64.3 & 33.6 \\
\hline CF10\% & 119.6 & 115.6 & 90.7 & 153.2 & 167.1 & 82.9 & 43.3 \\
\hline CF20\% & 118.8 & 115.7 & 70.2 & 154.4 & 168.2 & 64.1 & 33.5 \\
\hline CF30\% & 118.5 & 115.9 & 78.5 & 153.1 & 167.2 & 73.8 & 38.6 \\
\hline CF40\% & 119.7 & 116.1 & 62.5 & 152.9 & 166.1 & 60.5 & 31.8 \\
\hline
\end{tabular}

of the composites. In summary, $40 \%$ filler content had the best properties. As a result, the composites obtained from $\mathrm{PP}$ and lignocellulosic fillers have a better performance compared to PP, and the composites can be used as alternative materials in areas such as outdoor furniture, flowerpots, etc.

\section{Acknowledgement - Zahvala}

This study was supported by Bartin University, Scientific Research Projects Commission (Project No: 2013.1.90). The authors would like to thank the Scientific Research Projects Commission for providing the financial support.

\section{REFERENCES \\ 5. LITERATURA}

1. Ashori, A., 2008: Wood-plastic composites as promising green-composites for automotive industries. Bioresources Technology, 99 (11): 4661-4667. https://doi. org/10.1016/j.biortech.2007.09.043.

2. Aydemir, D.; Kiziltas, A.; Kiziltas, E. E.; Gardner, D. J.; Gunduz, G., 2015: Heat treated wood-nylon 6 compos- ites. Composites Part B: Engineering, 68: 414-423. https://doi.org/10.1016/j.compositesb.2014.08.040.

3. Aydemir, D.; Uzun, G.; Gumuş, H.; Yildiz, S.; Gumuş, S.; Bardak, T.; Gunduz, G., 2016: Nanocomposites of polypropylene/nano titanium dioxide: effect of loading rates of nano titanium dioxide. Materials Science, 22 (3): 364-369.

https://doi.org/10.5755/j01.ms.22.3.8217.

4. Baeza, J.; Freer, J., 2001: Chemical characterization of wood and its components. In: Hon D. N. S.; Shiraishi, N. (eds.), Wood and cellulosic chemistry (pp. 275-384). Marcel Dekker Inc., New York.

5. Bledzki, A. K.; Gassan, J., 1999: Composites reinforced with cellulose based fibers. Progress in Polymer Science, 24 (2): 221-274. https://doi.org/10.1016/S0079-6700(98)00018-5.

6. Bouafif, H.; Koubaa, A.; Perré, P.; Cloutier, A., 2009: Effects of fiber characteristics on the physical and mechanical properties of wood plastic composites. Composites Part A: Application Science and Manufacturing, 40 (12): 1975-1981. https://doi.org/10.1016/j.compositesa.2009.06.003.

7. Falk, R. H.; McKeever, D. B., 2004: Recovering wood for reuse and recycling. In European COST E31 Confer- 
ence: Management of Recovered Wood Recycling Bioenergy and other Options. Thessaloniki: Thessaloniki University Studio Press.

8. Sobczak, L.; Brüggemann, O.; Putz, R. F., 2013: Polyolefin composites with natural fibers and wood-modification of the fiber/filler-matrix interaction. Journal of Application Polymer Science, 127 (1): 1-17. https://doi.org/10.1002/app.36935.

9. Ichazo, M. N.; Albano, C.; Gonzalez, J.; Perera, R.; Candal, M. V., 2001: Polypropylene/wood flour composites: treatments and properties. Composite Structures, 54 (2-3): 207214. https://doi.org/10.1016/S0263-8223(01)00089-7.

10. Ismail, H.; Suryadiansyah, A., 2004. Effects of Filler Loading on Properties of Polypropylene-Natural RubberRecycle Rubber Powder (PP-NR-RRP) Composites. Journal of Reinforced Plastics and Composites, 23 (6): 639-650. https://doi.org/10.1177/0731684404032869.

11. Joseph, P. V.; Joseph, K.; Thomas, S.; Pillai, C. K. S.; Prasad, V. S.; Groeninck, G.; Sarkissova, M., 2003: The thermal and crystallization studies of short sisal fiber reinforced polypropylene composite. Composite: Part A, 34 (3): 253-266. https://doi.org/10.1016/S1359-835X(02)00185-9.

12. Khan, J. A.; Khan, M. A.; Islam, R.; Gafur, A., 2010: Mechanical, thermal and interfacial properties of jute fabricreinforced polypropylene composites: Effect of potassium dichromate. Material Science and Application, 1 (6): 350-357. https://doi.org/10.4236/msa.2010.16051.

13. Kızıltaş, A., 2009: Microcrystalline Cellulose-Filled Engineering Thermoplastic Composites, A thesis, Master of Science, Maine, USA.

14. Khonsari, A.; Taghiyari, H. R.; Karimi, A.; Tajvidi, M., 2015: Study on the effects of wood flour geometry on physical and mechanical properties of wood-plastic composites. Maderas. Ciencia y Tecnología, 17 (3): 545-558. https://doi.org/10.4067/S0718-221X2015005000049.

15. Kruenate, J.; Tongpool, R.; Panyathanmaporn, T.; Kongrat, P., 2004: Optical and mechanical properties of pp modified by metal oxides. Surface and Interface Analysis, 36 (8): 1044-1047. https://doi.org/10.1002/sia.1833.

16. Liang, H.; Xie, F.; Chen, B.; Guo, F.; Jin, Z.; Luo, F., 2007: Miscibility and melting behavior of poly(ethylene terephthalate)/poly(trimethylene terephthalate) blends. J Appl Polym Sci., 107 (1): 431-437. https://doi.org/10.1002/app.27081.

17. Maiti, S. N.; Singh, K., 1986: Influence of wood flour on the mechanical properties of polyethylene. Journal of Application Polymer Science, 32 (3): 4285-4289. https://doi.org/10.1002/app.1986.070320341.

18. Myers, G. E.; Chahyadi, I. S.; Coberly, C. A.; Ermer, D. S., 1991: Wood flour/polypropylene composites: influence of maleated polypropylene and process and composition variables on mechanical properties. International Journal of Polymeric Materials, 15 (1): 21-44. https://doi.org/10.1080/00914039108031519.

19. Najafi, S. K., 2013: Use of recycled plastics in wood plastic composites-A review. Waste Management, 33: 1898-1905. https://doi.org/10.1016/j.wasman.2013.05.017.

20. Okamoto, T., 2003: Recent developments in wood/plastic composites - Extrusion of wood-based materials. Mokuzai Gakkaishi, 49 (6): 401-407.

21. Oksman, K.; Sain, M., 2008: Wood-polymer composites. CRC Press, England. https://doi.org/10.1201/9781439832639
22. Osswald, T. A.; Menges, G., 1995: Materials science of polymers for engineers. Carl Hanser Verlag GmbH Co KG, Munich.

23. Pandey, K. K. A., 1999: Study of chemical structure of soft and hardwood and wood polymers by FTIR spectroscopy. Journal of Applied Polymer Science, 71 (12): 1969-1975. https://doi.org/10.1002/(SICI)1097-4628 (19990321)71:12<1969::AID-APP6>3.0.CO;2-D.

24. Raghu, H.; Bose, S.; Mahanwar, P. A., 2006. Effect of Particle Size of Filler on Coloration and Properties of High Density Polyethylene. Journal of Mineral and Materials characteristics and Engineering, 5 (1): 87- 100.

25. Roger, M. R., 2005: Handbook of Wood Chemistry and Wood Composites. In: Tshabalala, M. A.; Jakes, J.; VanLandingham, M. R.; Wang, S.; Peltonen, J. (eds.), $8^{\text {th }}$ Chapter: Surface Characterization (pp. 217-247), CRC Press, Boca Raton.

26. Rowell, R. M.; Sanadi, A. R.; Caulfield, D. F.; Jacobson, R. E., 1997: Utilization of natural fibers in plastic composites: problems and opportunities. LignocellulosicPlastic Composites, 23-51.

27. Yang, F.; Nelson, G. L., 2006: Polymer/silica nanocomposites prepared via extrusion. Polymer for Advanced Technology, 17 (4): 320-326. https://doi.org/10.1002/pat.695.

28. Valles-Rosales, D. J.; Rodríguez-Picón, L. A.; MéndezGonzález, L. C.; del Valle-Carrasco, A.; Alodan, H., 2016: Analysis of the mechanical properties of woodplastic composites based on agriculture Chili pepper waste. Maderas. Ciencia y Tecnología, 18 (1): 43-54. https://doi.org/10.4067/S0718-221X2016005000005.

29. Wechsler, A.; Hiziroglu, S., 2007: Some of the properties of wood-plastic composites. Building and Environment, 42 (7): $2637-2644$. https://doi.org/10.1016/j.buildenv.2006.06.018.

30. Verbicky, J. W.; Mark, H. F.; Bikales, N. M.; Overberger, C. G.; Menges, G., 1988: Encyclopedia of Polymer Science and Engineering, $2^{\text {nd }}$ ed. USA.

31. Wittig, W., 1994: Kunststoffe im Automobilbau. VDIVerlag, Dusseldorf.

32. Woodhams, R. T.; Thomas, G.; Rodgers, D. K., 1984. Wood fibers as reinforcing fillers for polyolefins. Polymer Engineering and Science, 24 (15): 1166-1671. https://doi.org/10.1002/pen.760241504

33. Zor, M.; Tankut, N.; Kızıltas, A.; Gardner, D. J.; Yazıcı, H., 2016: Feasibility of Using Foamed Styrene Maleic Anhydride (SMA) Co-polymer in Wood Based Composites. Drvna industrija, 67 (4): 399-407. https://doi.org/10.5552/drind.2016.1624.

\section{Corresponding address:}

\section{Dr. MUSTAFA ZOR, Ph. D.}

Department of Material and Material Processing Technology

Caycuma Vocational School

University of Bulent Ecevit 67900

Caycuma/Zonguldak, TURKEY

e-mail: mustafa.zor@beun.edu.tr 